\section{SUHU PERMUKAAN LAHAN DAN INTENSITAS PEMANFAATAN RUANG DI PERKOTAAN YOGYAKARTA}

\author{
Lanthika Atianta \\ Prodi S1 Perencanaan Wilayah dan Kota, SAPPK, ITB \\ Gedung Labtex IX-A Sugianto Soegijoko \\ Jl. B, Lb. Siliwangi, Kota Bandung, Jawa Barat - 40132
}

\author{
Jurnal Pengembangan Kota (2020) \\ Volume 8 No. 2 (151-162) \\ Tersedia online di: \\ http://ejournal2.undip.ac.id/index.php/jpk \\ DOI: $10.14710 /$ jpk.8.2.151-162
}

\begin{abstract}
Abstrak. Penelitian bertujuan untuk menemukan hubungan suhu permukaan lahan (SPL) dan intensitas pemanfaatan ruang di Perkotaan Yogyakarta. Data SPL didapatkan dari pengolahan citra Landsat OLI 8 perekaman bulan Juni tahun 2018 dengan metode Split Window Analysis (SWA). Variabel operasional intensitas pemanfaatan ruang meliputi KDB, KLB, KDH, dan jumlah lantai. Data intensitas pemanfaatan ruang didapatkan dengan observasi secara langsung melalui 80 sampel yang disebar di Perkotaan Yogyakarta. Hasil pengolahan Landsat menunjukkan SPL Perkotaan Yogyakarta pada tahun 2018 berada pada rentang $28,28^{\circ} \mathrm{C}$ sampai $41,92^{\circ} \mathrm{C}$ dengan rata-rata $36,2^{\circ} \mathrm{C}$. Suhu tinggi terkonsentrasi di pusat kota dan menurun pada area pinggiran. Hasil observasi lapangan menujukkan intensitas pemanfaatan ruang di Perkotaan Yogyakarta cukup tinggi dengan rata-rata nilai KDB 62\%, KLB 1,1 dan KDH 32\%. Analisis keterkaitan menunjukkan bahwa intensitas pemanfaatan ruang memiliki hubungan kuat dengan SPL. Variabel KDB, KLB dan jumlah lantai memiliki keterkaitan positif dengan SPL, sebaliknya KDH memiliki keterkaitan negatif dengan SPL.
\end{abstract}

Kata Kunci: Intensitas Pemafaatan Ruang; Landsat; Perkotaan Yogyakarta; Suhu Permukaan Lahan

[Title: Land Surface Temperature and Intensity of Space Utilization in Mega Urban Area of Yogyakarta]. The study aims to determine the relationship between land surface temperature (LST) and intensity of space utilization in the Mega Urban Area of Yogyakarta. LST data is obtained by processing the Landsat using the Split Window Analysis method. The space utilization data is obtained by observed 80 samples. The operational variables of space utilization are Building Coverage Ratio (BCR), Floor Average Ratio (FAR), Green Average Ratio (GAR), and the number of floors. The analysis shows that $L S T$ is in the range $28,28^{\circ} \mathrm{C}$ to $41,92^{\circ} \mathrm{C}$ and the average is $36,2^{\circ} \mathrm{C}$. The highest temperature is concentrated in the city center and decreasing in the hinterland area. The result shows that generally, the area has $B C R$ 62\%, FAR 1,1, and GAR 32\%. Moreover, LST has a strong relationship with the intensity of space utilization. BCR, FAR and the number of floors have a positive relationship to the LST, while the green area has a negative relationship with LST in the Mega Urban Area of Yogyakarta.

Keyword: Space Utilization Intensity; Landsat; Yogyakarta city; Land Surface Temperature

Cara Mengutip: Atianta, Lanthika. (2020). Suhu Permukaan Lahan dan Intensitas Pemanfaatan Ruang di Perkotaan Yogyakarta. Jurnal Pengembangan Kota. Vol 8 (2): 151-162. DOI: 10.14710/jpk.8.2.151-162

\section{PENDAhUluAN}

Kota sebagai pusat peradaban berperan besar dalam keberlangsungan kehidupan penduduk, baik penduduk di pusat kota dan disekitarnya. Peningkatan jumlah penduduk di perkotaan dipicu oleh pertumbuhan penduduk alami dan angka migrasi masuk yang terus meningkat. Intensitas alih fungsi lahan terus meningkat sebagai wujud pemenuhan kebutuhan ruang untuk mendukung aktivitas di Perkotaan. Lahan terbuka hijau menjadi ruang yang dikorbankan sebagai wujud eksternalitas aktualisasi aktivitas perkotaan. Minimnya ruang terbuka hijau menyebabkan degradasi lingkungan dan terancamnya keberlanjutan ruang di Perkotaan. Perubahan iklim mikro menjadi salah satu dampak nyata minimnya ketersediaan ruang hijau di Perkotaan (Yang, Jin, Xiao, Jin, Xia, Li, \& Wang, 2019). Hal ini semakin diperparah dengan adanya aktivitas manusia dan pembangunan perkotaan yang dapat 
meningkatkan anthropogenic heat di perkotaan (Kurnis, 2016).

Kawasan perkotaan yang didominasi oleh area terbangun dan segala aktivitas yang ada didalamnya membuat suhu udara perkotaan lebih tinggi dibandingkan daerah sekitarnya (Atianta, 2017; Jatmiko, 2016). Jika kondisi tersebut dibiarkan dalam jangka lama akan memicu munculnya fenomena SUHI. Surface Urban Heat Island (SUHI) merupakan fenomena perbedaan rata-rata suhu permukaan antara pusat kota dengan daerah di sekitarnya. Beberapa penelitian menemukan distribusi area SUHI dari tahun ke tahun terus mengalami peningkatan (Chi, Shi, \& Kuang, 2015; Nakata, Souza, \& Rodrigues, 2015). Hasil analisis di Kota Bandung (1994-2004) menunjukkan luas area dengan suhu tinggi $\left(30^{\circ} \mathrm{C}-\right.$ $35^{\circ} \mathrm{C}$ ) mengalami peningkatan sebesar $4,47 \%$ (12.606 ha) setiap tahunnya (Tursilowati, 2013). Selanjutnya di Kota Semarang luasan area dengan suhu yang tinggi meningkat sebesar $8,4 \%$ dan di Kota Surabaya sebesar 4,8\% (Tursilowati, 2013).

Pemanfaatan citra sebagai salah satu sumber data untuk identifikasi SPL sudah banyak dilakukan. Citra mampu memberikan informasi perubahan SPL dengan resolusi temporal dan spasial yang baik. Landsat merupakan salah satu citra dengan resolusi yang cukup baik secara spasial maupun temporal. Lebih lanjut citra Landsat dapat diunduh secara gratis melalui website resmi USGS. Selain penelitian terkait perekaman dan analisis secara temporal beberapa peneliti mulai mengidentifikasi faktor yang berpengaruh terhadap nilai SPL. Identifikasi diawali dari adanya hubungan antara jenis tutupan lahan dengan SPL yang akan dihasilkan.

Secara umum guna lahan berpengaruh terhadap nilai SPL (Tran, Pla, Latorre-Carmona, Myint, Caetano, \& Kieu, 2017). Hal ini dikarenakan adanya perbedaan karakteristik material tutupan lahan dan nilai albedo (Kurnis, 2016; Li, Kamarianakis, Ouyang, Turner II, \& Brazel, 2017; Sun, Gao, Li, Wang, \& Liu, 2019). Hasil penelitian menunjukkan NDVI berpengaruh terhadap nilai SPL yang dihasilkan. NDVI (Normalized Difference Vegetation Index) adalah nilai yang menunjukkan tingkat kehijauan atau tutupan vegetasi suatu wilayah. Dengan demikian, NDVI berbanding terbalik dengan nilai LST (Chun \& Guldmann, 2014; Guntara, 2015; Jatmiko, 2016). Selain itu, adapun faktor NDBI yang juga berpengaruh terhadap perubahan nilai SPL. NDBI (Normalized Difference Built-Up Index) digunakan untuk memetakan area lahan terbangun di wilayah amatan. Hasil penelitian menunjukkan bahwa nilai SPL berbanding lurus dengan NDBI (Chun \& Guldmann, 2014; Jatmiko, 2016).

Hasil temuan hubungan NDBI dengan LST menjadi dasar pemikiran bahwa bentuk ruang berkontribusi terhadap nilai LST yang dihasilkan (Guo, Zhou, Wu, Xiao, \& Chen, 2016; Parvez, Aina, \& Balogun, 2019; Yin, Yuan, Lu, Huang, \& Liu, 2018). Bentuk ruang mengacu pada tata ruang dan bentuk unsur perkotaan, termasuk tata guna lahan, prasarana transportasi, prasarana air dan energi, serta bentuk fisik pembangunan yang memfasilitasi aktivitas manusia dan interaksi di dalamnya (Alobaydi, Bakarman, \& Obeidat, 2016; Yin dkk., 2018). Bentuk ruang secara detail mencerminkan variasi tutupan lahan yang memiliki perbedaan material dan nilai albedo. Beberapa penelitian menerjemahkan bentuk ruang tersebut dalam beberapa variable operasional, diantaranya kepadatan, ketinggian bangunan dan sky view factor (SVF).

Melalui pemanfaatan citra dengan resolusi spasial yang tinggi, beberapa penelitian mulai dilakukan untuk menemukan pengaruh LST dan bentuk ruang. Penelitian terkait hubungan LST dan bentuk ruang diawali dengan temuan pengaruh faktor kepadatan bangunan yang menunjukkan bahwa kepadatan bangunan berbanding lurus dengan nilai LST yang dihasilkan (Guo dkk., 2016; Li dkk., 2017; Yang dkk., 2019). Lebih lanjut faktor KLB dan ketinggian bangunan berbanding terbalik dengan

ISSN 2337-7062 @ 2020

This is an open access article under the CC-BY-NC-ND license (http://creativecommons.org/licenses/by-nc-sa/4.0/). - lihat halaman depan (c) 2020

*Email lanthika@sappk.itb.ac.id

Diterima 13 Oktober 2020, disetujui 30 November 2020 
suhu yang dihasilkan (Guo dkk., 2016; Yin dkk., 2018). Kawasan dengan nilai KLB dan ketinggian bangunan yang tinggi memiliki suhu dan perbedaan yang relatif lebih rendah. Lebih lanjut Yin dkk. (2018) menemukan peningkatan faktor sky view factor (SVF) meningkatkan suhu dan memicu perbedaan suhu antara perkotaan dengan kawasan yang lainnya semakin tinggi.

Menanggapi kondisi tersebut, saat ini beberapa bangunan mulai menerapkan prinsip ecobuilding. Tatanan elemen terbangun (urban layout) dan material terbangun berpengaruh terhadap kemampuan objek dalam menyerap energi dari penyinaran matahari (Febrianti \& Sofan, 2014). Teknologi mulai dikembangkan untuk mewujudkan tata bangunan dan ruang yang nyaman. Konsep vertical garden maupun rooftop garden menjadi salah satu bentuk inovasi dan adaptasi untuk mewujudkan area hijau di perkotaan yang berfungsi untuk menurunkan suhu di Perkotaan. Selain itu beberapa juga sudah memanfaatkan angin untuk mengurangi dan mengalirkan udara panas yang ada di tengah kota (Yang dkk., 2019). Meskipun demikian, perkotaan masih belum mampu mewujudkan ruang yang nyaman secara termal dan masih menjadi permasalahan yang harus diselesaikan.

Perkotaan Yogyakarta dengan kecenderungan pertumbuhan penduduk yang pesat diikuti dengan isu alih fungsi lahan yang cukup tinggi memiliki ancaman cukup besar terhadap fenomena peningkatan suhu perkotaan (Manik, 2017). Data BPS menunjukkan luas sawah di Daerah Istimewa Yogyakarta pada tahun 2006 hingga tahun 2015 mengalami penurunan sebesar $4,82 \%$ dengan rata-rata laju penurunan sebesar $0,48 \%$ per tahun. Rata-rata SPL di Perkotaan Yogyakarta meningkat $0,99^{\circ} \mathrm{C}$ dari tahun 1992 dan 2009 dan berlanjut hingga tahun 2017 (Atianta, 2017; Hidayati, 2013; Wicahyani \& Izzati, 2013). Sebagai dampaknya, sebesar $51 \%$ area (17 kecamatan) di Perkotaan Yogyakarta memiliki nilai kenyamanan termal diatas ambang batas normal (Utomo, 2016). Kondisi inilah yang mendorong untuk dilakukan penelitian lebih lanjut terkait identifikasi hubungan SPL dengan intensitas pemanfaatan ruang khususnya di Perkotaan Yogyakarta. Adapun tujuan dari penelitian ini yaitu (i) identifikasi SPL di bulan Juni tahun 2018; (ii) identifikasi intensitas pemanfaatan ruang; dan (iii) identifikasi hubungan SPL dan intensitas pemanfaatan ruang di Perkotaan Yogyakarta.

\section{METODE PENELITIAN}

Penelitian ini menggunakan pendekatan deskriptif dengan metode analisis kuantitatif. Data yang digunakan dalam penelitian adalah data primer yang didapatkan dari observasi lapangan. Selanjutnya data sekunder didapatkan dari dokumen perencanaan, peraturan maupun website resmi dari pemerintah maupun instansi yang lain. Citra Landsat perekaman bulan Juni tahun 2018 menjadi sumber data untuk analisis LST. Distribusi sampling dilakukan secara purposive baik untuk sampel validasi SPL maupun intensitas pemanfaatan ruang di Perkotaan Yogyakarta.

\subsection{Analisis Suhu Permukaan Lahan (SPL)}

Analisis SPL dilakukan dengan menggunakan citra Landsat 8 dengan perekaman bulan Juni Tahun 2018. Analisis SPL dilakukan dengan menggunakan metode Split Window Algorithm (SWA). SWA adalah formulasi matematika diamis yang mampu menyajikan infromasi suhu permukaan lahan (Guntara, 2015; Latif, 2014). Metode SWA membutuhkan nilai brightness temperature yang diturunkan dari nilai TOA Reflectance band 10 dan band 11 (inframerah termal) pada sensor TIRS citra Landsat 8. Nilai LSE (Emisivitas Permukaan Lahan) yang diturunkan dari nilai FVC (Pecahan Tutupan Vegetasi) dari band 4 (merah) dan band 5 (inframerah dekat) pada sensor OLI citra Landsat-8 untuk estimasi suhu permukaan lahan (USGS, 2013). Validasi SPL hasil intepretasi citra Landsat dilakukan untuk mengetahui akurasi hasil analisis yang telah dilakukan terhadap kondisi yang ada di lapangan. Suhu permukaan di lapangan didapatkan melalui observasi terhadap 80 titik amatan yang tersebar di perkotaan Yogyakarta. Pemilihan sampel secara purposive, yaitu mewakili setiap kelas suhu lahan dan tutupan lahan. Pengukuran SPL dilakukan dengan menggunakan termometer inframerah pada pukul 09.00-11.00 WIB pada saat cuaca cerah selama 5 hari yaitu pada tanggal 30 
Mei - 3 Juni 2018. Selanjutnya analisis nilai RMSE (Root Mean Square Eror) dan NMAE (Normalized Mean Absolute Error) dilakukan untuk validasi intepretasi SPL Landsat. Jika hasil NMAE < 30\% maka hasil intepretasi menunjukkan bahwa adanya kesesuaian hasil intepretasidengan kondisi di lapangan (Kartikasari, Jaelani, \& Winarso, 2016). Gambar 1 menunjukkan distribusi sampel untuk validasi SPL di Perkotaan Yogyakarta tahun 2018.

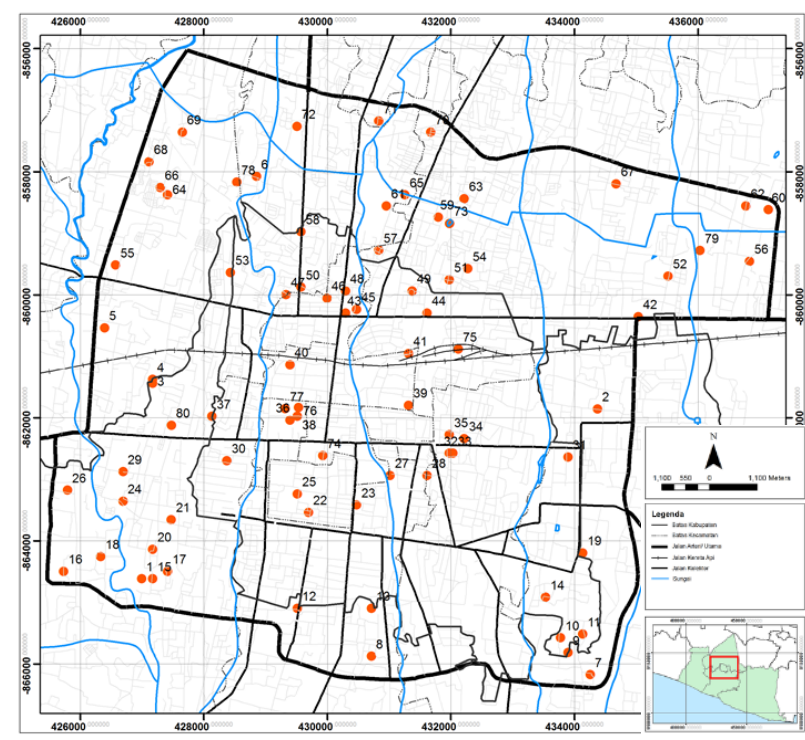

Gambar 1. Sebaran Sampel Validasi SPL dan Intensitas Pemanfaatan Ruang Perkotaan Yogakarta Tahun 2018 Sumber: RBI, Google Earth dan Analisis 2018

\subsection{Analisis Intensitas Pemanfaatan Ruang}

Berdasarkan hasil kajian pustaka terhadap beberapa penelitian yang sudah dilakukan, variabel operasional intensitas pemanfaatan ruang mengacu pada pedoman tata ruang di Indonesia. Pemanfaatan ruang adalah upaya untuk mewujudkan struktur ruang dan pola ruang sesuai dengan rencana tata ruang melalui penyusunan dan pelaksanaan program beserta pembiayaannya (Permen ATR No.17 Tahun 2017). Sesuai dengan lampiran Permen ATR No. 16 Tahun 2018, Intensitas pemanfaatan ruang meliputi $\mathrm{KDB}, \mathrm{KDH}$, KLB, Tapak Basement dan Kepadatan Bangunan. Dalam penelitian ini, variabel operasional yang digunakan untuk menunjukkan intensitas pemanfaaatan ruang meliputi KDB, KDH, KBD dan jumlah lantai bangunan. Data intensitas pemafaatan ruang didapatkan dari perhitungan data sekunder yang selanjutnya dilakukan verifikasi melalui pengamatan secara langsung di lapangan. Dalam penelitian ini, data intensitas pemafaatan ruang yang digunakan merupakan kondisi eksisting untuk setiap lokasi amatan yang dijadikan sampel. Analisis KDB dan KDH dihitung dengan menggunakan informasi dari google earth dan diverifikasi di lapangan. Selanjutnya untuk variabel jumlah lantai dan nilai KLB didapatkan dari pengamatan di lapangan secara langsung. Jumlah dan distribusi sampel yang digunakan sama dengan sampel untuk verifikasi SPL, yaitu sebanyak 80 sampel intensitas pemanfaatan ruang dan dapat dilihat pada gambar 1.

Dasar perhitungan variabel operasional intensitas pemanfaatan ruang, dianalisis sesuai dengan pedoman lampiran I Permen ATR No.17 Tahun 2017 tentang Audit Tata Ruang. Secara umum teknis analisis sebagai berikut :

a. Koefisien Dasar Bangunan (KDB) adalah perbandingan antara luas bangunan dengan luas lahan. Nilai KDB di suatu kawasan menentukan berapa persen luas bangunan di suatu kawasan yang boleh dibangun. Nilai terendah untuk KDB adalah $0 \%$ yang menunjukkan area tersebut merupakan area non terbangun dan nilai KDB tertinggi adalah $100 \%$ yang menunjukkan area terbangun dan padat bangunan.

b. Koefisien Dasar Hijau (KDH) didefinisikan sebagai angka persentase perbandingan antara luas seluruh ruang terbuka di luar bangunan gedung yang diperuntukkan bagi pertamanan/ penghijauan dengan luas lahan/bidang tanah yang dikuasai sesuai rencana tata ruang dan rencana tata bangunan dan lingkungan. Nilai $\mathrm{KDH}$ berbanding terbalik dengan nilai KDB. Nilai terendah untuk KDB adalah $0 \%$ yang menunjukkan bahwa area tersebut adalah area terbangunsedangkan nilai tertinggi adalah $100 \%$ yang menunjukkan area non terbangun.

c. Koefisien Lantai Bangunan (KLB) merupakan perbandingan antara jumlah seluruh luas lantai bangunan dengan pada luas lahan/bidang tanah yang dapat dibangun. Berbeda dengan 2 koefisien sebelumnya, nilai KLB bukan persentasi. Nilai terendah untuk KLB adalah 0 yang menunjukkan bahwa area tersebut adalah non terbangun, dan nilai tertinggi KLB tidak 
dapat ditentukan karena mengikuti nilai KDB dan jumlah lantai untuk masing-masing lokasi.

\subsection{Analisis Hubungan Intensitas Pemanfaatan Ruang dan SPL}

Hasil intepretasi SPL menjadi dasar untuk mengetahui hubungan SPL dengan intensitas pemanfaatan ruang. Analisis yang digunakan adalah analisis korelasi dengan menghitung nilai pearson antara SPL dengan variabel intensitas tersebut. Analisis ini memungkinkan untuk identifikasi hubungan, arah dan kekuatan hubungan antara kedua variabel tersebut. Selain uji korelasi, uji hipotesis juga dilakukan untuk mengetahui kecenderungan hasil temuan sampel terhadap kecenderungan yang terjadi secara populasi, dalam hal ini adalah Perkotaan Yogyakarta. Hipotesis null yang digunakan dalam uji hipotesis ini adalah tidak ada hubungan antara SPL dan intensitas pemanfaatan ruang di Perkotaan Yogyakarta. Dengan demikian, uji hipotesis mampu memperkuat hasil temuan bahwa hubungan SPL dan intensitas pemanfaatan ruang ini tidak hanya terjadi di dalam sampel yang diambil, namun juga terjadi pada populasi lokasi amatan. Analisis ini dilakukan dengan menggunakan tingkat kepercayaan sebesar $95 \%$.

Lebih lanjut, analisis regresi dilakukan untuk menemukan sifat hubungan antara SPL dan Intensitas pemanfaatan ruang di Perkotaan Yogyakarta. Sifat hubungan kedua variabel tersebut ditunjukkan melalui model secara sistematis. Identifikasi sifat hubungan ini menggunakan analisis multiple regresi dengan metode enter. Sifat hubungan antara SPL dan intensitas pemanfaatan ruang divalidasi dengan menggunakan nilai $R^{2}$ dan $F$ untuk mengetahui signifikansi model matematis yang dihasilkan.

\section{HASIL DAN PEMBAHASAN}

Dalam penelitian ini, hasil penelitian akan disajikan dalam 3 bagian pembahasan yaitu hasil identifikasi SPL bulan Juni tahun 2018, hasil identifikasi pemanfaatan ruang dan hasil temuan hubungan SPL dengan intensitas pemanfaatan ruang di Perkotaan Yogyakarta.

\subsection{Suhu Permukaan Lahan Perkotaan Yogyakarta}

Berdasarkan hasil analisis intepretasi citra Landsat OLI 8 perekaman bulan Juni, Perkotaan Yogyakarta tahun 2018 memiliki rata-rata SPL $36,2^{\circ} \mathrm{C}$. Validasi SPL dilakukan untuk mengetahui akurasi hasil intepretasi dengan kondisi di lapangan. Berdasarkan hasil analisis 80 sampel amatan di lapangan dengan intepretasi melalui citra landsat, hasil analisis RMSE SPL Perkotaan Yogyakarta adalah 2,52 . Hal ini menunjukkan bahwa terdapat selisih sebesar $2,52^{\circ} \mathrm{C}$ antara SPL hasil intepretasi dengan kondisi di lapangan. Nilai SPL pengukuran secara langsung cenderung memiliki nilai yang lebih tinggi dibandingkan nilai SPL hasil intepretasi dikarenakan terjadi kontak langsung dengan atmosfer dengan jarak yang relatif dekat (Jatmiko, 2016) dan tidak ada penghalang objek seperti udara maupun awan antara alat ukur suhu permukaan dengan obyek amatan pada pengukuran SPL secara langsung. Selanjutnya analisis NMAE dilakukan untuk uji akurasi hasil intepretasi citra landsat dengan kondisi di lapangan. Berdasarkan hasil analisis nilai NMAE SPL Perkotaan Yogyakarta adalah 5,91. Hal tersebut menunjukkan bahwa SPL hasil intepretasi landsat mampu menggambarkan suhu di Perkotaan Yogyakarta karena besar kesalahan pengolahan citra masih kurang dari 30\% (Kartikasari dkk., 2016). Dengan demikian dapat disimpulkan bahwa hasil intrepetasi SPL landsat dapat digunakan sebagai dasar untuk analisis lebih lanjut. Gambar 2 menunjukkan distribusi spasial suhu permukaan di perkotaan Yogyakarta bulan Juni tahun 2018.

Bila dirinci untuk setiap kelas suhu, SPL tertinggi di Perkotaan Yogyakarta perekaman tahun 2018 mencapai $41,92^{\circ} \mathrm{C}$ yang terletak di pusat Perkotaan Yogyakarta. Hasil observasi lapangan menunjukkan bahwa tutupan lahan di suhu tertinggi berada di kawasan Malioboro. Selanjutnya SPL terendah yaitu $28,28^{\circ} \mathrm{C}$ yang terletak di pinggir Perkotaan Yogyakarta (Kelurahan Maguwoharjo) dengan tutupan lahan berupa area budidaya tambak ikan. Bila ditinjau dari luasan distribusi kelas SPL, gambar 1 menunjukkan distribusi suhu $37^{\circ} \mathrm{C}$ memiliki persentase luas yang paling besar dibandingkan kelas suhu yang lain, yaitu mencapai 
$24,67 \%$ dari total luas wilayah amatan. Sebaliknya kelas suhu $28^{\circ} \mathrm{C}$ memiliki persentase luas yang paling kecil yaitu hanya 0,001\%. Jika dilihat dari distribusi spasial SPL, suhu diatas rata-rata SPL (yaitu $>36,2^{\circ} \mathrm{C}$ ) terkonsentrasi di pusat Perkotaan
Yogyakarta (Kota Yogyakarta). Sebaliknya suhu yang rendah $\left(28,28^{\circ} \mathrm{C}\right)$ tersebar didaerah pinggiran (mendekati bagian terluar ringroad). Perbedaan suhu ini terletak pada rentang $1^{\circ} \mathrm{C}-4^{\circ} \mathrm{C}$.

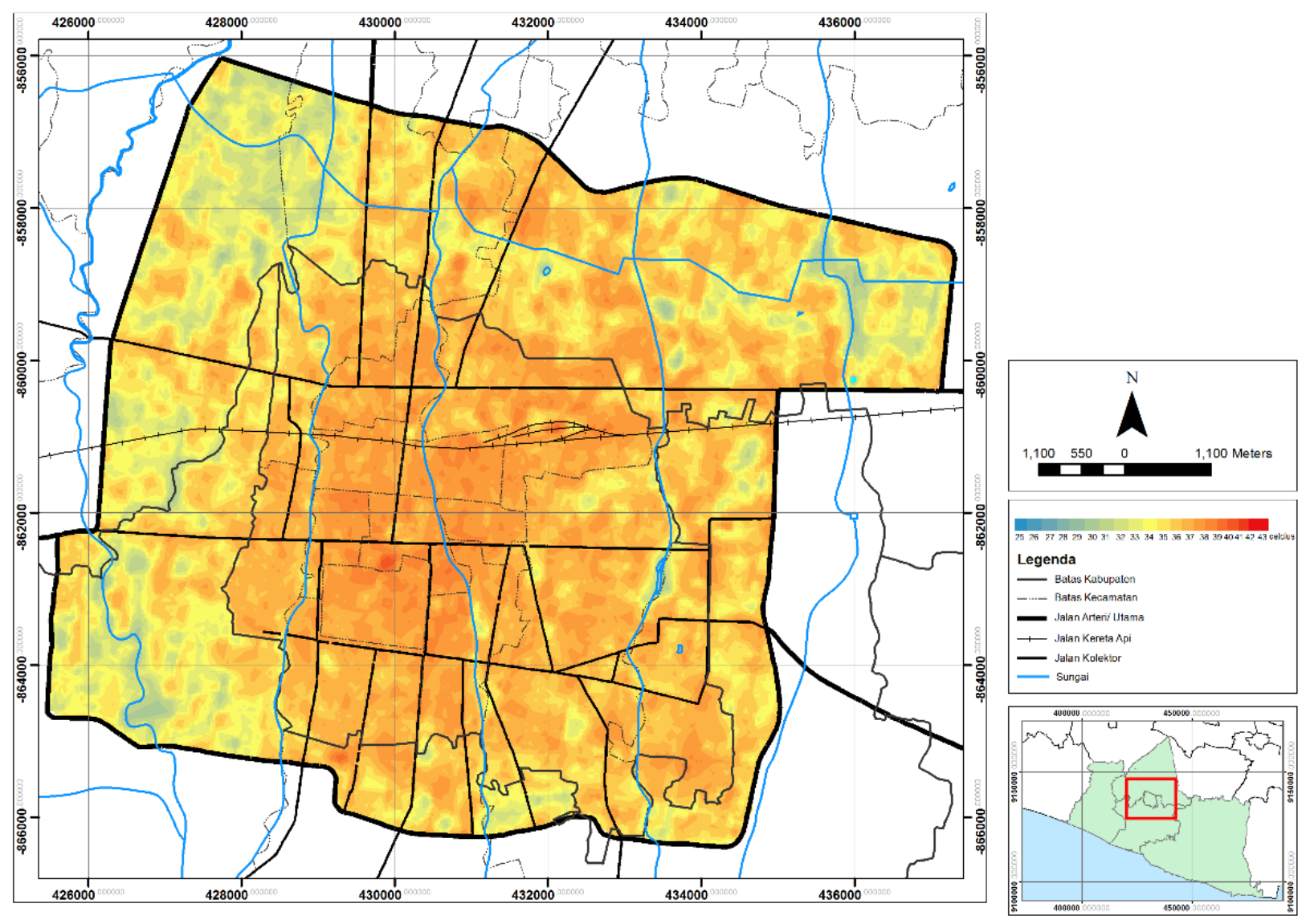

Gambar 2. Suhu Permukaan Lahan (SPL) di Perkotaan Yogyakarta Bulan Juni Tahun 2018 Sumber: Landsat OLI 8 Bulan Juni 2018, Analisis Penulis 2018

\subsection{Intensitas Pemanfaatan Ruang di Perkotaan Yogyakarta Tahun 2018}

Ruang lingkup dalam penelitian ini adalah Perkotaan Yogyakarta yang didefiniskan sebagai area yang berada dalam jalan lingkar (ringroad) Kota Yogyakarta. Berdasarkan definisi tersebut, Perkotaan Yogyakarta memiliki luas wilayah sebesar 81,865 Ha. Secara administratif kawasan penelitian terdiri dari seluruh kecamatan di Kota Yogyakarta dan sebagian kecamatan yang ada di Kabupaten Sleman dan Bantul. Beberapa kecamatan di Kabupaten Sleman yang masuk dalam Perkotaan Yogyakarta antaralain Kecamatan Gamping, Depok, Mlati dan Ngaglik. Selanjutnya Kabupaten Bantul meliputi Kecamatan Kasihan,
Sewon dan Banguntapan. Gambar 3 menunjukkan peta guna lahan Perkotaan Yogyakarta tahun 2018.

Dalam peta tersebut, sebesar $86,44 \%$ wilayah di Perkotaan Yogyakarta merupakan area terbangun dan $78,76 \%$ diantaranya adalah kawasan permukiman. Dilihat dari sebaran spasial, area permukiman secara merata terdistribusi di seluruh area Perkotaan Yogyakarta. Selanjutnya fasilitas penunjang aktivitas perkotaan (perdagangan, jasa, perkantoran, pendidikan) terkonsentrasi di pusat kota. Sebaliknya, area non terbangun (seperti sawah dan semak belukar) berada di kawasan pinggiran perkotaan. 


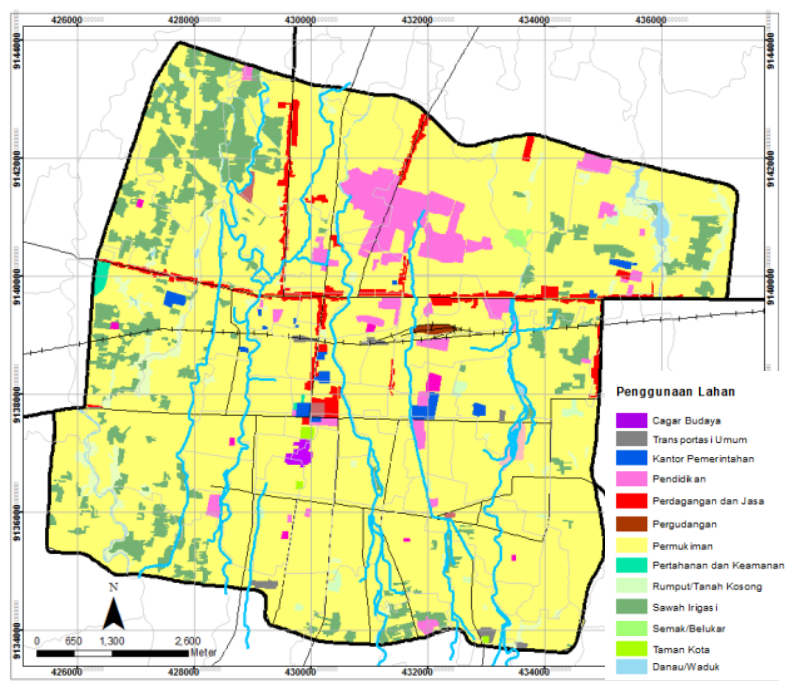

Gambar 3. Penggunaan Lahan di Perkotaan Yogyakarta Sumber : BIG, 2016 dan DPTR DIY 2018

Dominasi lahan terbangun di kawasan Perkotaan Yogyakarta membuat sebagian besar sampel merupakan area terbangun. Hasil observasi menunjukkan bahwa $85 \%$ sampel amatan merupakan area terbangun dan sisanya berupa area non terbangun. Tabel 1 menjelaskan secara rinci sebaran titik sampel dan penggunaan lahan eksisting Perkotaan Yogyakarta Tahun 2018.

Tabel 1. Sampel Amatan Analisis dan Jenis

Penggunaan Lahan di Perkotaan Yogyakarta Tahun 2018

\begin{tabular}{|c|l|c|c|}
\hline No & \multicolumn{1}{|c|}{ Penggunaan Lahan } & $\begin{array}{c}\text { Jumlah } \\
\text { sampel }\end{array}$ & $\%$ \\
\hline I & Non Terbangun & \multicolumn{2}{|c|}{} \\
\hline 1 & Alun-Alun/ Taman Kota & 1 & $1,25 \%$ \\
\hline 2 & Kebun/ Tanah kosong & 2 & $2,5 \%$ \\
\hline 3 & $\begin{array}{l}\text { Badan Air (kolam/ } \\
\text { sungai) }\end{array}$ & 2 & $2,5 \%$ \\
\hline 4 & Sawah & 7 & $8,75 \%$ \\
\hline II & Terbangun & 56 & $70 \%$ \\
\hline 1 & Perumahan & 6 & $7,5 \%$ \\
\hline 2 & Pendidikan & 3 & $3,75 \%$ \\
\hline 3 & Perdagangan dan Jasa & 1 & $1,25 \%$ \\
\hline 4 & Pergudangan & 1 & $1,25 \%$ \\
\hline 5 & Kantor Pemerintahan & 1 & $1,25 \%$ \\
\hline 6 & Transportasi & $\mathbf{8 0}$ & $\mathbf{1 0 0 \%}$ \\
\hline & \multicolumn{2}{|c|}{ Total } &
\end{tabular}

Sumber : Observasi lapangan dan analisis, 2018

Jika ditelusuri lebih lanjut, sebesar $70 \%$ sampel diantaranya berupa kawasan perumahan. Hal ini terjadi karena kawasan perkotaan Yogyakarta merupakan kawasan perkotaan yang padat sehingga semakin besar pula kemungkinan untuk mendapatkan sampel berupa kawasan terbangun. Jika dirinci lebih lanjut, kawasan terbangun yang menjadi sampel amatan penelitian ini terdiri dari (1) kawasan perumahan, (2) kawasan perdagangan dan jasa, (3) kawasan pendidikan, (4) kawasan perkantoran, (5) pergudangan, dan (6) sarana transportasi umum. Selanjutnya untuk kawasan non terbangun meliputi (1) Taman Kota (RTHP), (2) badan air/ sungai, (3) Kebun/ Tanah kosong. Data sampel selanjutnya akan menjadi basis data untuk analisis intensitas pemanfaatan ruang di Perkotaan Yogyakarta.

Tabel 2 menunjukkan rata-rata nilai KDB, KDH, KLB dan jumlah lantai di Perkotaan Yogyakarta tahun 2018. Secara umum perkotaan Yogyakarta merupakan kawasan terbangun dengan intensitas pemanfaatan lahan yang cukup tinggi. Hal ini ditunjukkan dengan nilai rata-rata KDB mencapai $62 \%, \mathrm{KDH} 32 \%$ dan KLB sebesar 1,14.

Tabel 2. Rata-Rata Intensitas Pemanfaatan Ruang di Perkotaan Yogyakarta Tahun 2018

\begin{tabular}{|l|c|c|c|c|}
\hline $\begin{array}{c}\text { Variabel } \\
\text { Operasional }\end{array}$ & KDB & KDH & KLB & $\begin{array}{c}\text { Jumlah } \\
\text { Lantai }\end{array}$ \\
\hline Min & 0 & 0 & 0 & 0 \\
\hline Max & 1 & 1 & 4 & 4 \\
\hline Rata-rata & 0,62 & 0,32 & 1,14 & 1,39 \\
\hline Standar Deviasi & 0,33 & 0,32 & 0,88 & 0,84 \\
\hline
\end{tabular}

Sumber : Observasi Lapangan dan Analisis, 2018

Analisis Koefisien Dasar Bangunan (KDB) dilakukan dengan membandingkan luas area terbangun dengan luas total area amatan. Berdasarkan observasi yang telah dilakukan, sebagian besar sampel merupakan area terbangun, khususnya adalah area perumahan. Rata-rata nilai KDB sampel amatan adalah sebesar $61,35 \%$ dengan nilai KDB terendah adalah $0 \%$ dan tertinggi adalah $100 \%$. Nilai KDB terendah berada pada area sawah (di daerah Ambarketawang) dan 100\% merupakan bangunan toko di area Jalan Malioboro. Sebesar $42,85 \%$ sampel amatan memiliki nilai KDB > 80\% dan Kawasan dengan tingkat kepadatan bangunan (KDB) yang tinggi terkonsentrasi di pusat kota Yogyakarta. Jika dikaitkan dengan peraturan RDTR Kota Yogyakarta (Perda Kota Yogyakarta No.1 Tahun 2015), hal tersebut selaras dengan ketentuan arahan pusat kota merupakan area yang direncanakan untuk kegiatan perdagangan jasa dan perumahan dengan intensitas pemanfaatan ruang yang tinggi. 
Koefisien Dasar Hijau (KDH) merupakan nilai koefisien perbandingan antara luas lahan tidak terbangun dengan luas total wilayah amatan. Nilai $\mathrm{KDH}$ berbanding terbalik dengan nilai KDB. Sebagai contoh kawasan perumahan padat penduduk (Sagan) memiliki KDH 0\% dan persawahan di Ambarketawan memiliki nilai KDH $100 \%$. Sejalan dengan hasil temuan analisis KDB, area dengan persentase $\mathrm{KDH}$ yang tinggi cenderung banyak ditemukan di area pinggiran Kota Yogyakarta. Meskipun demikian, akan ada kemungkinan kawasan pinggir perkotaan Yogyakarta juga akan berubah menjadi kawasan padat penduduk dengan mempertimbangkan trend perubahan lahan di Perkotaan Yogyakarta beberapa tahun ini. Gambar 4 menunjukkan perbedaan kawasan dengan nilai $\mathrm{KDH}$ dan KDB pada perumahan padat (Gondokusuman) dan sawah (Ambarketawang).
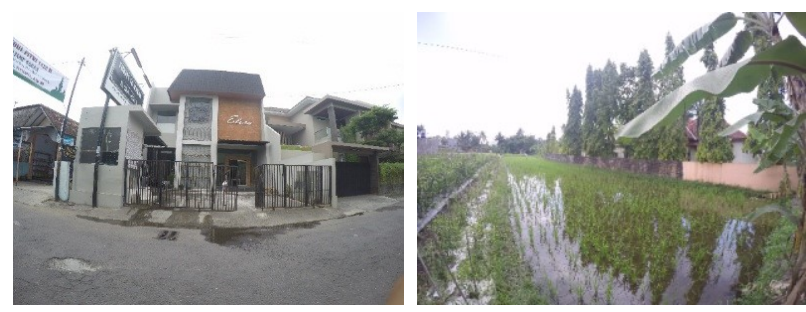

Gambar 4. KDB pada Area Perumahan di Gondokusuman (atas) dan Persawahan di Ambarketawang (bawah)

Sumber: Observasi Lapangan, 2018

Koefisien Lantai Bangunan (KLB) merupakan perbandingan antara jumlah seluruh luas lantai bangunan dengan total luas lahan. Berdasarkan hasil observasi yang telah dilakukan didapatkan bahwa rata-rata nilai KLB di perkotaan Yogyakarta adalah 1,1 . Jika nilai rata-rata KDB adalah 0,6 dapat disimpulkan bahwa secara umum bangunan di Perkotaan Yogyakarta terdiri dari 2 lantai. Secara spasial, sebaran nilai KLB juga mengikuti kecenderungan nilai KDB yaitu memusat di pusat Perkotaan Yogyakarta. Berdasarkan observasi lapangan, nilai KLB paling rendah adalah 0 dan nilai tertinggi mencapai 4. Gambar 5 menunjukkan nilai KLB tertinggi dan terendah hasil obervasi lapangan.

Kawasan Malioboro memiliki nilai KLB tertinggi dalam sampel amatan karena adanya arahan pemanfaatan ruang di RDTR Kota Yogyakarta. Dalam dokumen tersebut menyatakan bahwa kawasan Malioboro merupakan salah satu area komersil yang akan dikembangkan dengan intensitas pemanfaatan ruang yang tinggi. Sebaliknya, hasil obsrvasi menunjukkan sebagian besar tutupan lahan dengan nilai KLB 0 adalah area non terbangun yang berupa badan air (sungai), lahan kosong dan taman.
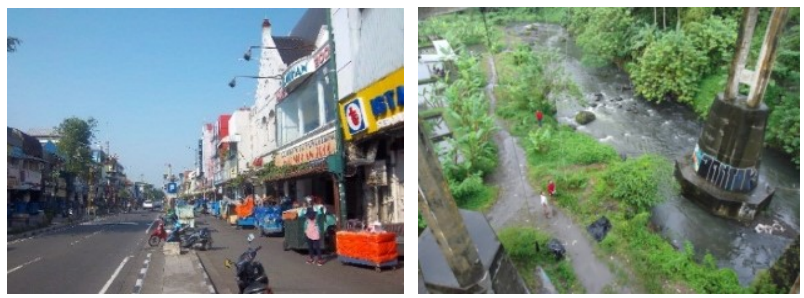

Gambar 5. KLB pada Kawasan Perdagangan di Malioboro (kiri) dan Badan Sungai di Maguwoharjo (kanan) Sumber : Observasi Lapangan, 2018

\subsection{Hubungan Intensitas Pemanfaatan Ruang dan Suhu Permukaan Lahan di Perkotaan Yogyakarta}

Sebelum melakukan analisis korelasi, uji normalitas data dilakukan untuk mengetahui distribusi data yang didapatkan. Berdasarkan uji normalitas data, nilai siginifikansi data intensitas pemanfaatan ruang dan SPL di Perkotaan Yogyakarta sebesar 0,68 . Hal ini menunjukkan bahwa data yang didapatkan sudah terdistribusi secara normal dan sudah dapat digunakan untuk analisis selanjutnya. Dalam penelitian ini analisis yang dilakukan adalah analisis korelasi dan uji hipotesis. Tabel 3 menunjukkan hasil analisis korelasi dan uji hipotesis SPL dan intensitas pemanfaatan ruang di Perkotaan Yogyakarta.

Tabel 3. Analisis Korelasi dan Uji Hipotesis SPL dengan Intensitas Pemanfaatan Ruang di Perkotaan Yogyakarta

\begin{tabular}{|l|c|c|c|c|}
\hline $\begin{array}{c}\text { Variabel } \\
\text { Operasional }\end{array}$ & KDB & $\begin{array}{c}\text { Jumlah } \\
\text { Lantai }\end{array}$ & KDH & KLB \\
\hline Rata-rata & 0,62 & 1,39 & 0,32 & 1,14 \\
\hline $\begin{array}{l}\text { Standar } \\
\text { Deviasi }\end{array}$ & 0,33 & 0,84 & 0,32 & 0,88 \\
\hline $\begin{array}{l}\text { Pearson } \\
\text { Corellation }\end{array}$ & 0,74 & 0,62 & $-0,87$ & 0,64 \\
\hline Sign. (2 tailed) & 0,00 & 0,00 & 0,00 & 0,00 \\
\hline Uji Hipotesis & $\mathrm{H} 1$ & $\mathrm{H} 1$ & $\mathrm{H} 1$ & $\mathrm{H} 1$ \\
\hline
\end{tabular}

Sumber: Analisis Penulis, 2018 
Hasil analisis yang tertulis dalam Tabel 3 menunjukkan bahwa variabel jumlah lantai bangunan memiliki korelasi yang paling rendah dan $\mathrm{KDH}$ yang paling tinggi. Bila dilihat arah hubungannya, variabel KDB, KLB dan jumlah lantai memiliki arah hubungan yang positif dengan SPL. Sebaliknya faktor KDH memiliki arah hubungan yang negatif dengan SPL. Melalui arah hubungan ini dapat diintepretasikan SPL akan meningkat apabila ada variabel KDB, KLB dan jumlah lantai meningkat, sebaliknya SPL akan menurun apabila variabel KDH mengalami peningkatan. Lebih lanjut uji hipotesis dilakukan. Berdasarkan hasil uji hipotesis yang telah dilakukan, didapatkan bahwa 5 variabel operasional intensitas pemanfaatan ruang memiliki nilai signifikansi $<0,05$ yang menunjukkan hubungan intensitas pemanfaatan ruang dan SPL tidak hanya terjadi pada sampel saja, namun juga terjadi pada populasi data yang digunakan, yaitu Perkotaan Yogyakarta.

Analisis regresi dilakukan untuk menemukan sifat hubungan SPL dan intensitas pemanfaatan ruang di Perkotaan Yogyakarta. Hasil analisis menunjukkan bahwa hubungan matematis SPL dan intensitas pemanfaatan ruang di Perkotaan Yogyakarta adalah $\mathrm{SPL}=38,882-5,560 \mathrm{KDH}$. Tabel 4 menunjukkan parameter siginfikansi model regresi yang dihasilkan antara SPL dan variabel $\mathrm{KDH}$ di Perkotaan Yogyakarta.

Tabel 4. Hasil Analisis Regresi Linear SPL dan KDH di Perkotaan Yogyakarta Tahun 2018

\begin{tabular}{|c|l|c|}
\hline No & \multicolumn{1}{|c|}{ Parameter Statistik } & Nilai \\
\hline 1 & $R$ & 0,87 \\
\hline 2 & R Square & 0,75 \\
\hline 3 & Adjusted $R$ & 0,75 \\
\hline 4 & F & 186,50 \\
\hline 5 & Sig F. change & 0,00 \\
\hline 6 & Durbin Watson & 1,36 \\
\hline 7 & Std. Error of the Estimate & 1,01 \\
\hline
\end{tabular}

Hasil analisis menunjukkan bahwa dari 4 variabel tersebut hanya 1 variabel yang dapat digunakan, yaitu variabel $\mathrm{KDH}$. Tidak terjadi multikoliniearitas dalam model yang ditunjukkan dari nilai durbin watson berkisar dari 1-2. Melalui model ini, variabel $\mathrm{KDH}$ hanya mampu menjelaskan $75,4 \%$ sisanya dijelaskan oleh variabel lain yang tidak digunakan dalam model. Dilihat dari nilai signifikansi $F$, model dapat digunakan sebagai alat prediksi karena nilai signifikansi $\mathrm{F}<0,05$.

\subsection{Hasil Temuan Penelitian dan Kajian Teori}

Perbedaan suhu antara pusat kota dan kawasan sekitarnya juga terjadi di Perkotaan Yogyakarta. Hasil analisis pengolahan citra Landsat 8 perekaman bulan Juni menunjukkan bahwa Perkotaan Yogyakarta memiliki perbedaan suhu yang cukup signifikan pada rentang $1^{\circ} \mathrm{C}-4^{\circ} \mathrm{C}$. Hal ini dikarenakan penggunaan lahan di pusat kota didominasi oleh kawasan terbangun (permukiman), sedangkan di area pinggiran masih terdapat area hijau. Pusat kota memiliki dominasi tutupan lahan berupa area terbangun dengan material yang bersifat massive dan memiliki nilai emisivitas yang tinggi. Pada umumnya material terbangun memiliki koefisien nilai albedo yang rendah, yang mengakibatkan pusat kota merefleksikan sedikit panas dan banyak menyerap energi panas yang diterima (Kurnis, 2016; Wardana, 2015). Sebaliknya, daerah pinggiran memiliki suhu yang lebih rendah karena didominasi oleh area tidak terbangun (lahan pertanian, taman kota dan badan air) yang cenderung memiliki nilai emisivitas yang rendah.

Lebih lanjut, hasil analisis korelasi antara intensitas pemanfaatan ruang dan SPL sesuai dengan hasil penelitian dan kajian pustaka yang sudah dilakukan. Nilai SPL berbanding lurus dengan nilai KDB, KLB dan jumlah lantai di Perkotaan Yogyakarta. Hasil analisis berupa nilai KLB berbeda dengan hasil penelitian yang sudah dilakukan (Guo dkk., 2016; Yin dkk., 2018). Hal ini dikarenakan suhu yang digunakan dalam penelitian ini adalah SPL bukan suhu udara sehingga ada perbedaan arah hubungan yang didapatkan. Selanjutnya, SPL berbanding terbalik dengan $\mathrm{KDH}$ yang mengakibatkan pinggir perkotaan cenderung memiliki suhu yang rendah dibandingkan pusat perkotaan (Chi dkk., 2015; Maru \& Ahmad, 2015).

\section{KESIMPULAN}

Rata-rata SPL Perkotaan Yogyakarta bulan Juni tahun 2018 sebesar $36,2^{\circ} \mathrm{C}$ dengan suhu terendah mencapai $28,28^{\circ} \mathrm{C}$ dan tertinggi $41,92^{\circ} \mathrm{C}$. Terdapat perbedaan suhu antara pusat kota dengan daerah sekitarnya yang mencapai $1^{\circ} \mathrm{C}-4^{\circ} \mathrm{C}$. Peta guna 
lahan tahun 2018 menunjukkan Perkotaan Yogyakarta didominasi oleh area permukiman dnegan intensitas pemanfaatan ruang yang tinggi. Hasil analisis korelasi menunjukkan bahwa variabel intensitas pemanfaatan ruang (KDB, KLB KDH dan jumlah lantai bangunan) memiliki hubungan dengan SPL di Perkotaan Yogyakarta. Lebih lanjut variabel $\mathrm{KDH}$ memiliki nilai korelasi yang paling tinggi dibandingkan variabel yang lain. Dengan demikian hasil penelitian diharapkan mampu menjadi pertimbangan dalam penentuan nilai ambang batas maksimal/ minimal intensitas pemanfaatan ruang, khususnya di Perkotaan Yogyakarta.

Penelitian terkait analisis SPL dan bentuk ruang perlu dilakukan lebih lanjut. Penelitian ini hanya fokus pada hubungan SPL di bulan Juni dengan kondisi intensitas pemanfaatan ruang di Perkotaan Yogyakarta. Adanya perbedaan cuaca dan lokasi geografis tentu akan berpengaruh terhadap nilai SPL maupun nilai hubungan dengan intensitas pemanfaatan ruang. Penelitian lebih lanjut sangat disarankan untuk menggunakan variabel operasional bentuk ruang maupun intensitas pemanfaatan ruang yang lain. Hal ini dikarenakan hasil temuan menunjukkan adanya variabel lain selain intensitas pemanfaatan ruang yang berpengaruh terhadap SPL.

\section{DAFTAR PUSTAKA}

Alobaydi, D., Bakarman, M. A., \& Obeidat, B. (2016). The Impact of Urban form Configuration on The Urban Heat Island: The Case Study of Baghdad, Iraq. Procedia Engineering, 145, 820-827. Doi: https://Doi.org/10.1016/j.proeng.2016.04. 107

Atianta, L. (2017). Pengaruh Intensitas Pemanfaatan Ruang terhadap SUHI (Surface Urban Heat Island) di Perkotaan Yogyakarta. (Thesis), Universitas Gadjah Mada, Yogyakarta.

Chi, W., Shi, W., \& Kuang, W. (2015). SpatioTemporal Characteristics of Intra-Urban Land Cover in The Cities of China and USA From 1978 to 2010. Journal of Geographical Sciences, 25(1), 3-18.
Chun, B., \& Guldmann, J.-M. (2014). Spatial Statistical Analysis and Simulation of The Urban Heat Island in High-Density Central Cities. Landscape and urban planning, 125, 76-88. Doi: https://Doi.org/10.1016/j. landurbplan.2014.01.016

Febrianti, N., \& Sofan, P. (2014). Ruang Terbuka Hijau di DKI Jakarta Berdasarkan Analisis Spasial dan Spektral Data Landsat 8. Paper presented at the Seminar Nasional Penginderaan Jauh, Bidang Lingkungan dan Mitigasi Bencana -LAPAN.

Guntara, I. (2015). Pemanfaatan Citra Landsat 8 untuk Mengestimasi Suhu Permukaan Lahan (Land Surface Temperature) di Kabupaten Bantul Menggunakan Split Window Algorithm. (Doctoral dissertation), Universitas Gadjah Mada, Yogyakarta.

Guo, G., Zhou, X., Wu, Z., Xiao, R., \& Chen, Y. (2016). Characterizing The Impact of Urban Morphology Heterogeneity on Land Surface Temperature in Guangzhou, China. Environmental Modelling \& Software, 84, 427-439. Doi: https://Doi.org/10.1016/j. envsoft.2016.06.021

Hidayati, I. N. (2013). Analisis Transformasi Citra dan Penggunaan/Penutup Lahan Terhadap Urban Heat Island Berbasis Citra Penginderaan Jauh. (Laporan Penelitian Hibah Penelitian Dosen), Universitas Gadjah Mada, Yogyakarta.

Jatmiko, R. H. (2016). Penggunaan Citra Saluran Inframerah Termal untuk Studi Perubahan Liputan Lahan dan Suhu sebagai Indikator Perubahan Iklim Perkotaan di Yogyakarta. (Doctoral dissertation), Universitas Gadjah Mada, Yogyakarta.

Kartikasari, F., Jaelani, L. M., \& Winarso, G. (2016). Analisis Sebaran Konsentrasi Suhu Permukaan Laut dan pH Untuk Pembuatan Peta Lokasi Budidaya Kerapu Bebek Menggunakan Citra Satelit Landsat-8 (Studi Kasus: Teluk Lampung, Lampung). Jurnal Teknik ITS, 5(2), A401-A406. Doi: http://dx.Doi.org/10.12962/j23373539.v5i 2.17206

Kementerian Agraria dan Tata Ruang Republik Indonesia. (2017). Peraturan Menteri Agraria dan Tata Ruang/ Kepala Badan 
Pertanahan Nasional Nomor 17 Tahun 2017 Tentang Pedoman Audit Tata Ruang. Kementerian Agraria dan Tata Ruang.

Kementerian Agraria dan Tata Ruang Republik Indonesia. (2018). Peraturan Menteri Agraria dan Tata Ruang Nomor 16 Tahun 2018 tentang Pedoman Penyusunan Pedoman Penyusunan Rencana Detail Tata Ruang dan Peraturan Kabupaten Kota. Kementerian Agraria dan Tata Ruang.

Kurnis, E. (2016). Spatial Modeling of Land Surface Temperature and Its Relationship with Ecological Factors in Bogor Municipality. (Thesis), IPB Bogor.

Latif, M. S. (2014). Land Surface Temperature Retrival of Landsat-8 Data Using Split Window Algorithm-A Case Study of Ranchi District. International Journal of Engineering Development and Research, 2(4), 2840-3849.

Li, X., Kamarianakis, Y., Ouyang, Y., Turner II, B. L., \& Brazel, A. (2017). On The Association Between Land System Architecture and Land Surface Temperatures: Evidence From A Desert Metropolis-Phoenix, Arizona, USA. Landscape and urban planning, 163, 107-120. Doi: https://Doi.org/10.1016/j.landurbplan.201 7.02 .009

Manik, T. K. (2017). The Impact of Urban Heat Islands: Assesing Vulnerability in Indonesia. British Journal of Environment and Climate Change, 7(02), 119-134.

Maru, R., \& Ahmad, S. (2015). The Relationship Between Temperature Patterns and Urban Morfometri in the Jakarta city, Indonesia. Asian Journal of Atmospheric Environment, 9(2), 128-136. Doi: https://Doi.org/10.5572 /ajae.2015.9.2.128

Nakata, C., Souza, L. C. L., \& Rodrigues, D. S. (2015). A GIS Extension Model to Calculate Urban Heat Island Intensity Based on Urban Geometry. Paper presented at the The 14th International Conference on Computers in Urban Planning and Urban Management. http://hdl.handle.net/1822 /38845

Parvez, I. M., Aina, Y. A., \& Balogun, A.-L. (2019). The Influence of Urban Form on The Spatiotemporal Variations in Land Surface Temperature in An Arid Coastal City.
Geocarto International, 1-20. Doi: https://Doi.org/10.1080/10106049.2019.1 622598

Pemerinta Daerah Kota Yogyakarta. (2015). Peraturan Daerah Kota Yogyakarta Nomor 1 Tahun 2015 tentang Rencana Detil Tata Ruang Kota Yogyakarta Tahun 2015-2035. Pemerinta Daerah Kota Yogyakarta.

Sun, Y., Gao, C., Li, J., Wang, R., \& Liu, J. (2019). Quantifying The Effects of Urban Form on Land Surface Temperature in Subtropical High-Density Urban Areas Using Machine Learning. Remote Sensing, 11(8), 959. Doi: https://Doi.org/10.3390/rs11080959

Tran, D. X., Pla, F., Latorre-Carmona, P., Myint, S. W., Caetano, M., \& Kieu, H. V. (2017). Characterizing The Relationship Between Land Use Land Cover Change and Land Surface Temperature. ISPRS Journal of Photogrammetry and Remote Sensing, 124, 119-132. Doi: https://Doi.org/10.1016 /j.isprsjprs.2017.01.001

Tursilowati, L. (2013). Urban Heat Island dan Kontribusinya pada Perubahan Iklim dan Hubungannya dengan Perubahan Lahan. Paper presented at the Seminar Nasional Pemanasan Global dan Perubahan Global. Fakta, mitigasi, dan adaptasi. Pusat Pemanfaatan Sains Atmosfer dan Iklim LAPAN.

USGS. (2013). USGS Landsat Missions: Using the USGS Landsat 8 Product. Retrieved 20 April, 2019, from http://landsat.usgs.gov /Landsat8_Using_Product.php

Utomo, A. T. (2016). Luas Tutupan Vegetasi dan Variasi Indeks Kenyamanan Termal pada Tahun 2002 dan 2014 di Kawasan Perkotaan Yogyakarta. (Skripsi), Universitas Gadjah Mada, Yogyakarta.

Wardana, I. K. (2015). Analysis of Urban Surface Temperature for Green Spaces Planning in Bandung City, Indonesia. (Thesis), University of Twente.

Wicahyani, S., \& Izzati, M. (2013). Pulau Bahang Kota (Urban Heat Island) Di Yogyakarta Hasil Interpretasi Citra Landsat Tm Tanggal $28 \mathrm{Mei}$ 2012. Paper presented at the Seminar Nasional Pengelolaan Sumberdaya Alam dan Lingkungan Tahun 2013.

Yang, J., Jin, S., Xiao, X., Jin, C., Xia, J. C., Li, X., \& Wang, S. (2019). Local Climate Zone 
Ventilation and Urban Land Surface Temperatures: Towards A PerformanceBased and Wind-Sensitive Planning Proposal in Megacities. Sustainable Cities and Society, 47, 101487. Doi: https://Doi.org/10.1016/j.scs.2019.101487
Yin, C., Yuan, M., Lu, Y., Huang, Y., \& Liu, Y. (2018). Effects of Urban Form on The Urban Heat Island Effect Based on Spatial Regression Model. Science of the Total Environment, 634, 696-704. Doi: https://Doi.org/10. 1016/j.scitotenv.2018.03.350 